$\begin{array}{ll}\text { Abstracta Iranica } & \begin{array}{l}\text { Abstracta Iranica } \\ \text { Revue bibliographique pour le domaine irano-aryen }\end{array} \\ & \text { Volume } \mathbf{2 8} \mid \mathbf{2 0 0 7} \\ & \text { Comptes rendus des publications de } \mathbf{2 0 0 5}\end{array}$

\title{
The Secret of Laughter: Magical Tales from Classical Persia. London/New York, I.B. Tauris, 2005, 200 p.
}

Leili Anvar-Chenderoff

\section{OpenEdition}

Journals

Édition électronique

URL : http://journals.openedition.org/abstractairanica/20471

DOI : 10.4000/abstractairanica.20471

ISSN : 1961-960X

Éditeur :

CNRS (UMR 7528 Mondes iraniens et indiens), Éditions de l'IFRI

Édition imprimée

Date de publication : 15 mai 2007

ISSN : 0240-8910

Référence électronique

Leili Anvar-Chenderoff, « The Secret of Laughter: Magical Tales from Classical Persia. London/New York, I.B. Tauris, 2005, 200 p. », Abstracta Iranica [En ligne], Volume 28| 2007, document 322, mis en ligne le 18 septembre 2007, consulté le 25 septembre 2020. URL : http://journals.openedition.org/ abstractairanica/20471; DOI : https://doi.org/10.4000/abstractairanica.20471

Ce document a été généré automatiquement le 25 septembre 2020.

Tous droits réservés 


\title{
The Secret of Laughter: Magical Tales from Classical Persia. London/ New York, I.B. Tauris, 2005, 200 p.
}

\author{
Leili Anvar-Chenderoff
}

1 Shusha Guppy nous livre ici en anglais un joli livre dans lequel elle raconte 18 contes persans dans le style gracieux qu'on lui connaît. La plupart sont des contes populaires appartenant à la tradition orale (seuls deux sont directement tirés du Šāh-nāme et du Matnavĩ : l'histoire de Bīžan et Manīže et l'histoire du solțān Maḥmūd et de la bande des voleurs). Comme elle l'explique elle-même, elle a voulu raconter ces contes conservés dans sa mémoire depuis l'enfance afin qu'ils soient sauvé de l'oubli. Son travail n'a aucune prétention universitaire mais peut être considéré comme une source documentaire pour qui s'intéresse à la tradition orale des contes en Iran, en plus d'être un simple plaisir de lecture.

\section{INDEX}

Thèmes : 11.1.0. Généralités

\section{AUTEURS}

LEILI ANVAR-CHENDEROFF

INaLCO - Paris 